\title{
Monetary Policy and Deposit Money Banks’ Lending Rates in Nigeria
}

\author{
Demehin, James Adeniyi \\ Department of Banking and Finance, Adekunle Ajasin University Akungba-Akoko, Ondo State, Nigeria
}

\begin{abstract}
Lending rates are vital prices that influence consumption and investment spending decisions of economic units, and thus, the central banks of nations are saddled with the responsibility of ensuring that the rates charged by deposit money banks are providing enabling financial environment, and this responsibility is being discharged by adopting appropriate monetary policy stances taking cognizance of the prevailing macroeconomic conditions. On this premise, this study examined the effect of monetary policy on deposit money banks' lending rates in Nigeria. Secondary data was obtained from central bank of Nigeria statistical bulletin from 1987 to 2018. Augmented Dickey Fuller, Bound test, and Autoregressive Distributed Lag were used to determine the effect of money supply, monetary policy rates, and cash reserve ratios on lending rates. The stationary results indicated that lending rates and monetary policy rates were stationary at level, and money supply and cash reserve ratios stationary at first difference. Bound test results showed that there were long run relationships between the dependent and the independent variables. From the Autoregressive Distributed Lag results, money supply had positive and insignificant effect on lending rates in the short- run but negative and significant effect in the long-run. Cash reserve ratios exerted positive and significant effect in the short run, and negative and insignificant in the long run. Monetary policy rates influence was positive and significant both in the short run and long run. It was concluded that, with monetary policy rates showing the potency to influence the direction of lending rates, monetary policies would go a long way in producing monetary management capable of generating increased growth with stability in Nigeria. It was equally recommended that the central bank of Nigeria should identify banks funds sources that were outside its control and institute control mechanism in order to improve cash reserve ratios potency both in the short run and long run, and strengthen monetary policies effectiveness.
\end{abstract}

Key Words: Deposit money banks, central bank, lending rates, monetary policy, macroeconomic conditions

\section{INTRODUCTION}

$\mathrm{D}$ eposit money banks' roles in the saving and investment process of any nation remain pertinent, hence, their activities are of great concerns to monetary authorities. As financial intermediaries, they mobilize funds, channel same for productive activities and charge interest for the services rendered. In other to evolve efficient monetary management that is growth-inducing, central banks all over the world focused on the activities of deposit money banks considering the central roles played by them, not only in their primary functions of acceptance of deposits and granting of loans and advances but also in ensuring efficient payment system. The central bank of Nigeria, in order to realize price stability, and manage economic fluctuations, influences the lending rates of credit granted by the country's deposit money banks through one of its macroeconomic management tool which is monetary policy.

Monetary policy, according to the Central Bank of Nigeria (2006), was referred to as specific actions taken by the Central Bank to regulate the value, supply and cost of money in the economy with a view to achieving government's macroeconomic objectives. Thus, monetary management function is carried out by employing indirect method of monetary control in which monetary policy rate (MPR), cash reserve ratio (CRR), and open market operations (OMO) are used as instruments to influence bank credit, lending rates, and money supply referred to as the intermediate target variables used to achieve the ultimate objectives of increased and sustainable economic growth, balance of payment equilibrium, price level, and increased employment level. Monetary policy stance could be either expansionary or contractionary depending on the prevailing macroeconomic conditions. An expansionary policy connotes decreases in monetary policy rate, and cash reserve ratio which are expected to lead to a fall in the lending rates, while a contractionary policy does the exact opposite of expansionary policy.

However, figures from the Central Bank of Nigeria (CBN) statistical bulletin (2018) revealed that movements of lending rates with monetary policy rates, cash reserve ratios, and money supply in most cases over the years were not consistent with theoretical postulations or expectations. While money supply has been on the increase consistently from 1987 to 2018, monetary policy rates, lending rates, and cash reserve ratios have shown some contradicting movements.

In 1987, 1988, 1989 and 1990, monetary policy rates were $12.75 \%, 12.75 \%, 18.50 \%$, and $18.50 \%$ respectively while in the same periods, lending rates were $13.96 \%$ in $1987,16.61 \%$ in $1988,20.44 \%$ in 1989 and $25.3 \%$ in 1990 , and for cash reserve ratios, we had $7.5 \%$ in $1987,5.9 \%$ in $1988,5.7 \%$ in 1989 and $9.2 \%$ in 1990. Monetary policy rate remained same in 1988, cash reserve ratio decreased but lending rate increased to $16.61 \%$ in 1990 . Monetary policy remained at $18.50 \%$, lending rate rose to $25.3 \%$ while cash reserve ratio increased to $9.2 \%$. Again there were positive co-movement between monetary policy rates and lending rates in 1991 through 2007 but variances occurred in 2008 in which 
monetary policy rate increased to $9.75 \%$ from $9.50 \%$ in 2007 and lending rate fell from $16.94 \%$ in 2007 to $15.14 \%$ in 2009 , monetary policy rate fell to $6.00 \%$ and lending rate rose to $18.99 \%$. In 2010 , monetary policy rate increased to $6.25 \%$ while lending rate decreased to $17.59 \%$. Also, in 2011 through 2013, monetary policy rates stood at $12.00 \%$ which was higher than that of 2010 but lending rate fell to $16.02 \%$ in 2011 , increased to $16.79 \%$ in 2012 and decreased marginally to $16.72 \%$ in 2013 . Monetary policy rates and lending rates in 2014 and 2015 showed negative co-movements with monetary policy rates at $13.00 \%$ and down to $11.00 \%$ in 2014 and 2015 respectively, lending rates decreased to $16.55 \%$ in 2014 and increased to $16.85 \%$ in 2015 . With monetary policy rates stable at $14.00 \%$ in 2016,2017 , and 2018 , lending rates increased modestly from $17.08 \%$ in 2016 to $17.78 \%$ in 2017 and fell to $16.9 \%$ in 2018 .

In the same vein, movements in lending rates were inconsistent with variations in cash reserve ratios. In 1990, cash reserve ratio increased from $9.2 \%$ to $19.13 \%$ in 1991 , lending rates fell in the same period, from $25.50 \%$ to $20.01 \%$. Also, in 1992, cash reserve ratio decreased to $3.3 \%$ and lending rate rose to $24.75 \%$. The same negative comovements instead of positive co-movements occurred in 1993, 1994, 1995, 1996, 1997, 2002, 2006, 2009, 2011, 2014, and 2015 , cash reserve ratios were $4.57 \%, 4.37 \%, 4.50 \%$, $5.98 \%$ and $66.42 \%$ in 1993, 1994, 1995, 1996, and 1997 respectively while lending rates in the same periods were $18.32 \%, 21.00 \%, 20.18 \%, 19.74 \%$, and $13.54 \%$ respectively. Also, cash reserve ratio decreased from $10.76 \%$ in 2001 to $9.97 \%$ in 2002, and lending rate increased in the same periods from $18.29 \%$ to 2.85 . The same scenarios occurred in 2016 with cash reserve ratio increased to $5.38 \%$ and lending rate fell to $17.26 \%$; in 2009 , cash reserve ratio was $0.84 \%$ from $1.66 \%$ in 2008 , lending rate was $18.99 \%$ from $15.14 \%$; cash reserve ratio in 2011 rose to $5.78 \%$ from $0.84 \%$ in 2010 while lending rate fell to $16.02 \%$ from $17.59 \%$; cash reserve ratio equally rose to $17.99 \%$ in 2014 with lending rate decreased from $16.72 \%$ in 2013 to $16.55 \%$ in 2014 ; and in 2015 cash reserve ratio fell to $15.18 \%$ and lending rate increased to $16.85 \%$. Cash reserve ratios stood at $22.5 \%$ in 2016 to 2018 while lending rates were $17.08 \%, 17.78 \%$ and $16.91 \%$ in 20166, 2017 and 2018 respectively.

Considering the noticed inconsistencies in co-movements between monetary policy rates and lending rates on the one hand and cash reserves ratios and lending rates on the other hand coupled with the fact that the monetary policy committee does meet on quarterly basis to consider the nation's monetary developments in general and prevailing lending rates in particular in order to decide the next monetary action to embark on, this study will examine the effects of monetary policy, employing its instruments of monetary policy rates and cash reserves ratios, and the quantity of money available in the Nigerian economy, individually and jointly, on the deposit money bankss' lending rates. Specifically, the study will determine the nature of influence monetary policy rates have on lending rates in Nigeria. It will also examine the effect of cash reserves ratios on lending rates; and finally assess the influence of money supply on lending rates in Nigeria.

\section{LITERATURE REVIEW}

\section{Conceptual Review and Monetary Policy}

Monetary policy involves the use of monetary policy instruments to control cost and availability of money in the economy in order to affect the level of economic activities and growth. Falade and Folorunso (2015) described monetary policy as deliberate effort by the monetary authority to control the supply and the credit conditions for the purpose of achieving certain broad economic objectives which might be mutually exclusive.

Monetary policy consists of a government's formal efforts to influence and manage the volume of money in the economy in order to achieve some macroeconomic goals. Three basic kinds of monetary policy decisions can be made about the amount of money in circulation and the level of interest rate and the functions of credit markets and the banking system (Ogunjimi, 1997; Abata, Kehinde \& Bolarinwa, 2012). The main objectives of monetary policy for most developing economies include price stability, maintenance of balance of payments equilibrium, promotion of employment and output growth, and sustainable development. Udede (2014) listed the instruments of monetary policy adopted by Central Bank to include; Open Market Operation (OMO), Required Reserve Ratio (RRR), Bank Rate, Liquidity Ratio, Selective Credit Control and Moral Suasion.

\section{Empirical Literature}

Aliyu, Seidu, Zubair and Beki (2017) studied the effect of changes in Nigerian monetary policy rates on interest rates from 2006 to 2016 using the model monetary policy rate as a function of 91-day Treasury Bills, savings deposit, one month deposit, three months deposit, twelve months deposit, prime lending rate, maximum lending rate, inter-bank call policy instruments. It was found in the study that, monetary policy rates influenced the 91-day Treasury Bill rates in Nigeria; that lending rates, inter-bank call rates and 91-day Treasury bill rates considered together influence the monetary policy rates. In my opinion, this study constructed a wrong model by making monetary policy rate the dependent variable instead of being an independent variable as suggested by the topic. Again, there was no use of granger causality test which would have validated the finding that some of the variables considered together influence monetary policy rates.

In his work on the effects of monetary policy rates on interest rates in Nigeria, employing monthly data of bank retail rates and monetary policy rates from 2007 to 2012, and using multivariate vector Autoregressive model, Ikechukwu (2014) employed simple linear estimation of $B R R=f(M P R)$, where BRR implies Bank retail rates which were in the form of short-term interest rates (saving deposit rate, inter-bank rate, prime lending rate, maximum lending rate and long-term 
interest rates on 91-day Treasury bill rate) found that monetary policy was effective only in the relationship between monetary policy rates and inter-bank rates and that the weak link between monetary policy rates and savings deposit rate could be explained by low savings incentives. It was concluded that monetary policy changes through variation in monetary policy rates or stability in monetary policy rates had produced contradicts results in all the retail market rates with the exception of Treasury bill rates. A significant observation in the study was the use of simple linear estimation which was considered inadequate for this kind of study. In addition to monetary policy rates, inflation rate and money supply should have been considered.

Afolabi, Adeyemi, Salawudeen and Fagbemi (2018) investigated the relationship that could exist between monetary policy instruments and deposit money banks' loans and advances in Nigeria from 1981 to 2016. The model was Deposit Money Banks' Loans and Advances (DMBLA) as a function of Monetary Policy Rates (MPR), Lending Rate (LR), Money Supply (MS), Inflation Rate and Cash Reserve Ratio (CRR). The Toda and Yamamoto granger non-causality test was employed in the study. It was found that structural changes in monetary policy system exerted positive and significant impact on loans and advances of Deposit Money Banks (DMBs) in Nigeria. Bidirectional relationship was equally found to be existing between monetary policy rate and deposit money banks' loans and advances, and that other explanatory variables did not granger cause deposit money banks' loans and advances.

Monetary policy variables and deposit money bankss loans using causality approach was studied by Uwaizie and Aina (2015). The model was deposit money bankss loans and advances as a function of broad money supply, MPR, liquidity ratio, inflation rate and exchange rates. The study found that there was causal relationship between monetary policy variables and deposit money bankss loans and advances. Also, using Error Correction Model, disequilibrium of the system was found to be corrected at a speed rate of $89.2 \%$ yearly. In this study, it was noticed that lending rates, a vital factor in lending and borrowing was not considered. Lending rates could cause a change in the volume and value of deposit money bankss loans and advances and in the same way volume and value of the loans and advances could be influenced by changes in lending rates.

Odior (2013) investigated whether monetary policy (minimum rediscount rates, currency outside banks, net domestic credit, demand deposit and exchange rate) and deposit money banks lending can provide a convincing explanation for monetary inflation in Nigeria, over the period 1980-2010. It was revealed that monetary policy and bank lending rate do affect inflation partially and that exchange rate has insignificant effect on inflation. It was concluded that monetary policy and deposit money banks lending can provide partial explanatory effects on inflation in the Nigerian economy.
Akomolafe, et al (2015) examined the impact of monetary policy on deposit money bankss' performance in Nigeria in a micro-panel analysis. Interest rate and money supply were used as proxies for monetary policy, while profit before tax (PBT) was used to represent deposit money bankss' performance. Pooled regression, Fixed effect regression, and Random effect regression were all carried out in the analysis. The result showed that there was a positive relationship between banks' profits and monetary policies as proxied by money supply and interest rate. However, interest rate was not statistically significant at $1 \%$ and $5 \%$ levels.

Dhungana (2017) assessed the impact of monetary policy actions such as cash reserve ratio, open market operations and bank rate on bank lending using panel data of 24 deposit money bankss during the period 1996 to 2015 which were analyzed using descriptive statistics, correlation and regression analysis. The study showed that open market operations and cash reserve ratio had negative but bank rate had positive impact on bank lending.

Ndubuaku, Ifeanyi, Enze and Onyemere (2017) examined the impact of monetary policy regimes on the performance of deposit money bankss in Nigeria using regression and Pearson Product Moment Correlation technique to analyze the data collected while t-test statistic was employed in testing the hypotheses. It was discovered that monetary policy rate during pre-SAP period did not have significant impact on the total asset value, deposit mobilization, loans and advances and credit to the private sector while monetary policy rate during post SAP period had significant impact on the total assets value, deposit mobilization, loans and advances and credit to the private sector respectively.

\section{METHODOLOGY}

\section{Data collection}

This study employs time series data that ranges from 1987 to 2018. Data were secondary and were sourced from the Central Bank of Nigeria statistical Bulletin and World Development Indicators. The monetary management variables used are Lending Rate, Monetary Policy Rate, Cash Reserve Ratio, and Money Supply. The study period is between 1987 and 2018. The choice of 1987 is to give allowance for the full-fledged implementation of SAP for a whole year after it was pronounced.

\section{Model Specification}

This study employs multiple regression model which is given as;

$\mathrm{LR}=\mathrm{f}(\mathrm{MPR}, \mathrm{CRR}, \mathrm{MS})$

$\mathrm{LR}=\lambda_{0}+\lambda_{1} \mathrm{MPR}+\lambda_{2} \mathrm{CRR}+\lambda_{3} \mathrm{MS}+\varepsilon_{\mathrm{t}}$

Where:

LR = Lending Rate

MPR = Monetary Policy Rate

CRR $=$ Cash Reserve Ratio 
MS = Money Supply

$\lambda_{0}=$ Constant term

$\lambda_{1}-\lambda_{3}=$ Coefficient of the explanatory variables

$\varepsilon=$ Random error term

$\mathrm{t}=$ Time subscript

\section{Evaluation Techniques}

In evaluating the effect of monetary policy, measured as Monetary Policy Rates, Cash Reserves ratios, and Money Supply, on deposit money bankss' lending rates, Augmented Dickey Fuller Unit Root Test, Johansen Co-integration Test and Autoregressive Distributed Lag Model is employed. Augmented Dickey Fuller Unit Root will be employed to test the stationarity of the variables and to ascertain the order of integration of the variables so as to avoid the problem of spurious regression. Bounds co-integration Test will be used to determine long-run equilibrium relationships among the variables while the determination of the speed of adjustment among the variables and establishment of the relationships between the explanatory variables (MPR, CRR, and MS) and the explained variable (LR)

To test the statistical relationships among the variables, tstatistics will be used to determine significant or otherwise relationship between each of the independent variables and the dependent variable. Also, F-statistics will be adopted to examine the joint effect of Monetary Policy Rates (MPRs), Cash Reserve Ratios (CRRs) and Money Supply (MS) on Lending Rates (LRs), while Adjusted R-square will be employed to determine the explanatory power of the independent variables on the dependent variable.

\section{INTERPRETATION OF RESULTS}

\section{Test of Stationarity}

Table 1: Analysis of the Unit Root Test

\begin{tabular}{|c|c|c|c|c|c|c|c|}
\hline \multicolumn{4}{|c|}{ Level Form } & \multicolumn{3}{c|}{ First Differences } \\
\hline Variables & T-stat & $5 \%$ Critical Value & P-value & T-stat & $5 \%$ Critical Value & P-value & $\begin{array}{c}\text { Order of } \\
\text { Int. }\end{array}$ \\
\hline LR & -4.045988 & -2.963972 & 0.0040 & NA & NA & NA & $1(0)$ \\
\hline MS & 0.074347 & -3.568379 & 0.9954 & -6.377080 & -3.574244 & 0.0001 & $1(1)$ \\
\hline RR & -1.581101 & -2.963972 & 0.4796 & -4.016470 & -2.971853 & 0.0045 & $1(1)$ \\
\hline MPR & -2.986922 & -2.963972 & 0.0476 & NA & NA & NA & $1(0)$ \\
\hline
\end{tabular}

Source: Researcher's Computation, 2020

The series of the variables employed in this study are assessed for unit root using Augmented-Dickey Fuller test both at level and first difference which is depicted in table 1 . The results show that lending rate and monetary policy rate are stationary at level as indicated by the probability of the series which is significant at $5 \%$ while money supply and reserve ratio are not stationary at level. However, at first difference, money supply and reserve ratio are stationary at first difference. Thus, the null hypothesis of unit root is rejected for the variables. Since the variables are integrated at different order, the study proceeds to long run relationship using Bound Test.

\section{Co-integration Result}

Table 2: Bound Test

\begin{tabular}{|c|c|c|}
\hline Test Statistic & Value & $\mathrm{K}$ \\
\hline F-statistic & 5.128837 & 3 \\
\hline Critical Value Bounds & & \\
\hline Significance & $\mathrm{I}(0)$ Bound & $\mathrm{I}(1)$ Bound \\
\hline $10 \%$ & 2.72 & 3.77 \\
\hline $5 \%$ & 3.23 & 4.35 \\
\hline $2.5 \%$ & 3.69 & 4.89 \\
\hline $1 \%$ & 4.29 & 5.61 \\
\hline
\end{tabular}

Source: Researcher's Computation, 2020
The co-integration result which measures the long run relationship among the variables is presented in table 2 using Bound Test Co-integration technique. The result shows that the F-statistic value is given as 5.128837 which is greater than the lower bound critical value of 3.23 at $5 \%$. This implies there is long run equilibrium relationship among lending rate, money supply, crash reserve ratio and monetary policy rate which led to the rejection of the null hypothesis of no long run relationship among the variables.

\section{Autoregressive Distributed Lag}

Table 3: Short Run Co-integrating Form

\begin{tabular}{|c|c|c|c|c|}
\hline Variable & Coefficient & Std. Error & t-Statistic & Prob. \\
\hline DLOG(MS) & 0.000833 & 0.000760 & 1.095706 & 0.2856 \\
\hline DLOG(MS(-1)) & 0.001892 & 0.000970 & 1.949876 & 0.0647 \\
\hline D(CRR) & 0.444407 & 0.148193 & 2.998850 & 0.0068 \\
\hline D(MPR) & 0.738505 & 0.246965 & 2.990324 & 0.0070 \\
\hline CointEq(-1) & -1.056203 & 0.189310 & -5.579215 & 0.0000 \\
\hline
\end{tabular}

Source: Researcher's Computation, 2020

The short run co-integrating coefficient of the autoregressive distributed lag result is presented in table 3 . The result shows that money supply has positive and insignificant effect on lending rate and this contradicts the theory that money supply and lending rates should be 
inversely related. It equally implies that money supply effect is broken in the short run and that the transmission mechanism is weak.

The result also shows that reserve ratio has positive and significant effect on lending rate. This is an expected result, notwithstanding the noticed instances where reserve ratio and lending rate were moving in opposite directions in the raw data.

Furthermore, the result shows that monetary policy rate has positive and significant effect on lending rate. This confirms the level of reliance the Central Bank has placed on monetary policy rate in achieving its monetary policy objectives. Finally, result shows that there is speed of adjustment among the variables with a coefficient of 1.056203 which implies any deviation in the previous period will be corrected at $105 \%$ in the current period. This conformed with the result of Bound co-integration result which indicates there the macroeconomic variables moved together in the long run.

Table 4: Long Run Coefficient

\begin{tabular}{|c|c|c|c|c|}
\hline Variable & Coefficient & Std. Error & t-Statistic & Prob. \\
\hline LOG(MS) & -0.000431 & 0.000171 & -2.518070 & 0.0200 \\
\hline LOG(CRR) & -0.236720 & 0.157177 & -0.042754 & 0.9663 \\
\hline MPR & 0.699208 & 0.239118 & 2.924112 & 0.0081 \\
\hline C & 9.615090 & 3.405409 & 2.823476 & 0.0102 \\
\hline
\end{tabular}

Source: Researcher's Computation, 2020

Table 4 presents the result of the long run coefficient of the study. It is established in the long run that money supply has negative and significant effect on lending rate in the long run with a coefficient of -0.000431 . It could safely be said that it took a long transmission means before a change in money supply did affect lending rates.

Furthermore, the result shows that cash reserve ratio has negative and insignificant effect on lending rate with a coefficient of -0.236720 . This could be the case if funds that are not captured by reserve ratio or outside monetary control are available to the banks.

Finally, the long run result shows that monetary policy rate has positive and significant effect on lending rate with a coefficient of 0.699208. Again, this confirms the reliance of Central Bank on its use.

\section{CONCLUSION AND RECOMMENDATIONS}

In line with the findings, it was concluded that, with monetary policy rates showing the potency to influence the direction of lending rates, monetary policies will go a long way in producing monetary management capable of generating increased growth with stability in Nigeria. It was equally recommended that the central bank of Nigeria should identify banks funds sources that were outside its control and institute control mechanism over them in order to improve cash reserve ratios potency both in the short run and long run, and also improve on transmission mechanism in order to make changes in money supply effective in controlling lending rate.

\section{REFERENCES}

[1] Afolabi, M. A., Adeyemi, K. K., Salaudeen, O.S., \& Fagbemi, T.O. (2018). Monetary policy and bank credit in Nigeria: A TodaYamamoto approach. Journal of Acts Universitatis, Danubius. 14(5), 45-55.

[2] Akomolafe, K.J., Danladi, J.D., Babalola, O., \& Abah, A.G. (2015). Monetary policy and deposit money bankss' erformance in Nigeria. International Journal of Public Policy and Administration Research, 5(9), 1-15.

[3] Aliyu, S.B., Saidu, S.A., Ubair, A.U. \& Beki, D. (2017). Effect of changes in Nigeria monetary policy rates on interest rates. International Journal of Economics and Business Management, 3(10), 44-57.

[4] CBN (2018). Central Bank of Nigeria statistical bulletin, 25. Retrieved June 15, 2019, from http://statistics.cbn.gov.ng/cbnonlinestats.

[5] Central Bank of Nigeria monetary policy department. CBN/MPD/series 01/2006.

[6] Dhungana, N.T. (2017). Effects of monetary policy on bank lending in Nepal. International Journal of Business and Management Review, 4(7), 60-81.

[7] Falade, O.E. \& Folorunso, B.A. (2015). Fiscal and monetary policy instruments and economic growth sustainability in Nigeria. American Journal of Economics, 5(6), 587-594.

[8] Ikechukwu, K. (2014). Effects of monetary policy rates on interest rates in Nigeria. International Journal of Business and Finance Research, 8(1), 30-51.

[9] Ndubuaku, V.C. Ifeanyi, O. Enze, C. \& Onyemere, S. (2017). Impacts of monetary policy on deposit money bankss' profits: The case of Vietnam. Asian Social Science, 13(8), 32-40.

[10] Odior, E.S. (2013). Monetary policy, bank lending and inflation in Nigeria: VAR approach. Kashere Journal of Humanities, Management and Social Sciences, 11(2), 143-159.

[11] Udede, C.C (2014). Monetary policy and economic growth of Nigeria (1981-2012). Journal of Policy and Development Studies, 9(1), 23-247.

[12] Uwozie, I.U. \& Aina, T.H. (2015). Monetary policy variables and deposit money bankss' loans: A causality approach. Research Journal of Finance and Accounting, 6(18), 122-135. 